\title{
Evaluation of the feeding habits of Macrobrachium brasiliense (Heller, 1862) in the Curral de Arame stream (Dourados/Mato Grosso Do Sul, Brazil)
}

\author{
Madson Silveira de Melo and Jelly Makoto Nakagaki
}

Centro de Pesquisa em Biodiversidade - CPBio, Universidade Estadual de Mato Grosso do Sul, Cidade Universitária de Dourados, 79804-970, Dourados, MS, Brazil. E-mails: (MSM) madsonsilveira@hotmail.com; (JMN) jelly@uems.br

\begin{abstract}
Macrobrachium brasiliense is a cosmopolitan shrimp species found in the channel of large rivers, streams, lakes, igapós and upland igarapés and can present diversity in the use of food resources. This study aimed to evaluate the feeding habits according to sex, molt stage, seasonal and spatial variation, and size class. Organisms were collected every three months from May 2011 to March 2012 at three sampling sites in the Curral de Arame Stream, including the upstream, middle, and downstream sections. Animals were sampled with $50 \times 50 \mathrm{~cm}$ sieves ( $1 \mathrm{~mm}$ mesh size) on the margin, and with "D" dip nets $40 \mathrm{~cm}$ wide (500 $\mu \mathrm{m}$ mesh size) at the bottom. Of each animal we examined the sex, molt stage, carapace length, and stomach content. Data were analyzed through the frequency of occurrence and compared by a chi-square test. Four-hundred-thirty shrimps were collected, of which $26.05 \%$ male and $73.95 \%$ female; of the total males, $69.64 \%$ showed content in the stomach, and females, 72.96\%. Among food items stood out: Non-identified Organic Matter (90\%), Insects (89.68\%), Sand (87.10\%), Algae (49.03\%), Oligochaeta (29.68\%), Fungi (26.77\%) and Plant fragment $(14.52 \%)$. No significant difference was detected in the diet between males and females, but there was a seasonal difference related to the molt stage, and differences along the space and per size classes, and it was concluded that the species has omnivorous habits.
\end{abstract}

Key words: Crustacea, food habits, frequency of occurrence, Palaemonidae, stomach content

\section{INTRODUCTION}

The genus Macrobrachium Spence Bate, 1868 has more than 243 species registered in tropical and subtropical regions worldwide (De Grave and Frasen, 2011). Macrobrachium brasiliense (Heller, 1862) is a shrimp with wide geographical distribution, occurring in coastal basins of northern South America, from Venezuela to Brazil, and basins of the rivers
Orinoco, Amazonas, São Francisco, Paraguay and Paraná (Coelho and Ramos-Porto, 1985; Melo, 2003). Recently, the occurrence of this species was expand in several areas of its known distribution, and reported for the first time from the states of Amapá, Tocantins, and Mato Grosso do Sul (Pileggi et al., 2013). It can be found in the main channel of large rivers, streams, lakes, igapós and upland igarapés (García-Dávila et al., 2000). 
Studies on $M$. brasiliense include faunistic, taxonomic, population, reproductive and larval morphology surveys (Coelho and Ramos-Porto, 1985; García-Dávila et al., 2000; Vásquez et al., 2000; Mantelatto and Barbosa, 2005; Pereira and Chacur, 2009; Pantaleão et al., 2011), with little information on its feeding dynamics.

The maintenance of a population among other things depends on the food availability, the encounter between predator and prey and an appropriate energy transfer between trophic levels. In this way, the stomach content analysis is common for assessing the importance of the role of food in biological communities (Hyslop, 1980). Information from these studies is applied to several fields of research, such as trophic ecology, and probable uses in optimizing the farming of crustaceans.

The stomach content analysis could be providing important information on the food habit and its trophic position in a community. Besides that indicate the ecological relationships between organisms and interpretation of general dynamics of the environment (Aguirre-León and Yáñes-Arancibia, 1984), and also indicate their patterns of distribution, migration and ecdysis (Mclaughlin and Hebard, 1961).

Furthermore, the feeding habits may be directly related to the life-cycle stage and the increase in size, and hardness of the prey ingested can also be associated to the increment of the body size of the predator (Collins, 1999; Oh et al., 2001; Roux et al., 2009).

Studies involving the feeding of freshwater shrimps in their natural environment are uncommon due to the difficulty in determining and quantifying the stomach content, but some authors have significantly contributed to the knowledge of the subject (Chong and Sasekumar, 1981; Barros and Valenti, 1997; Albertoni et al., 2003; Jimoh et al., 2011). There is no information available on the natural diet of Macrobrachium brasiliense in Brazilian streams. The present study evaluated the feeding habits of $M$. brasiliense in the Curral de Arame Stream according to size, sex, molt stage, the seasonal and spatial variation.

\section{Material and Methods}

For the analysis of the diet of $M$. brasiliense samplings were carried out in May, September, and December 2011, and in March 2012 at three sampling sites in the Curral de Arame Stream, one near the headwaters (CA03 $\left.22^{\circ} 13^{\prime} 12.6^{\prime \prime S} / 54^{\circ} 55^{\prime} 05.9^{\prime \prime} \mathrm{W}\right)$ with relatively preserved riparian forest, one in the middle stretch of the stream (CA02 - 22018'02.3"S / 54051'17”W) an open area with degraded riparian forest and sugar cane plantation in the surroundings, and one downstream (CA01 $22^{\circ} 20^{\prime} 14.7^{\prime} \mathrm{S} / 54^{\circ} 50^{\prime} 45.7^{\prime \prime} \mathrm{W}$ ) an area with relatively degraded riparian forest and soybean and corn plantation in the surroundings (Fig. $1)$.

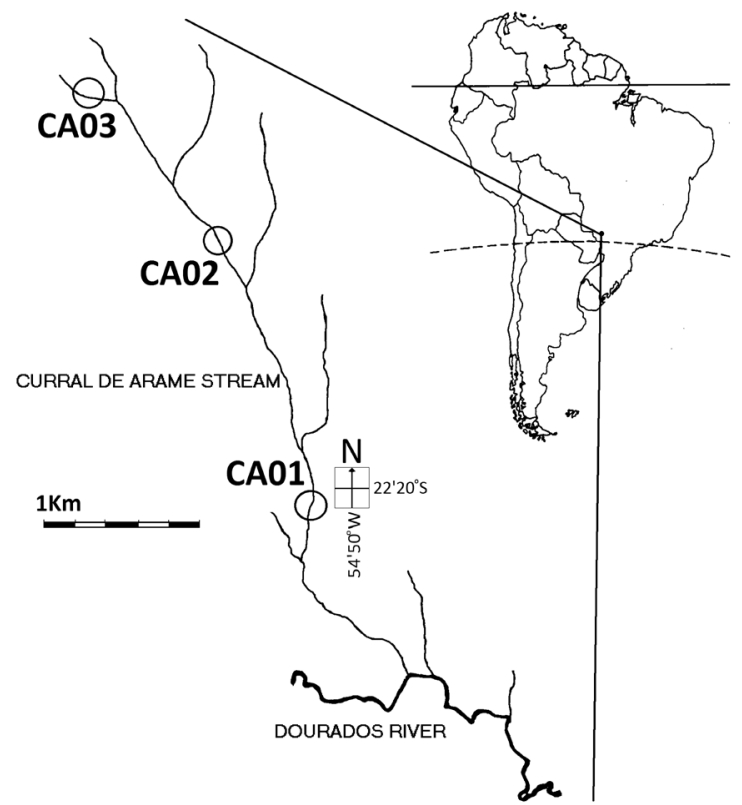

Figure 1. Curral de Arame stream showing de sampling sites of $M$. brasiliense.

Animals were collected with $50 \times 50 \mathrm{~cm}$ sieves ( $1 \mathrm{~mm}$ mesh size) on the margins, and "D"dipnets $40 \mathrm{~cm}$ wide $(500 \mu \mathrm{m}$ mesh size) for samplings at the bottom with litter, sand or rocks. The capture effort was 3 people for 30 minutes at each sampling site. Animals collected were immediately anesthetized in ice coolers and fixed with $70 \%$ alcohol to interrupt the digestion.

In laboratory, each animal was measured: carapace length (CL), distance between the postorbital groove to the dorsal posterior margin of the cephalothorax $(0.1$ $\mathrm{mm}$ ) individuals were grouped into six size 
classes and sexed according to the presence of internal appendix in the endopod of the second pair of pleopods. It was also observed the condition of molt, by distinguishing the individuals into intermolt with completely rigid exoskeleton $(\mathrm{C})$, newly molted with very soft exoskeleton (A), and in postmolt with the phase of calcification of the exoskeleton (B) not observed D and E stage, according Passano (1960) description for caridean.

Stomachs were removed by dorsal dissection of the cephalothorax and the content was examined by the numerical analysis method and frequency of occurrence, according to Hyslop (1980) and ZavalaCamin (1996). It has been assigned the fullness of the stomach according to Chong and Sasekumar (1981) and Josileen (2011) for all the stomachs, based on the amount of content in each one: 0 indicates an empty stomach, 1 a stomach that is $0.1-25 \%$ full, 2 one that is $25.1-50 \%$ full, 3 one that is $50.1-75 \%$ full and 4 one that is $75.1-100 \%$ full. The content was spread on a microscopy slide and analyzed. It was determined the percentage of stomachs of a given food item in relation to the total number of stomachs with any amount of food, ignoring totally empty stomachs, following the formula $\mathrm{FO} \%=$ ni/N.100, where, (ni) number of stomachs with the item $\mathrm{i}$ and $(\mathrm{N})$ total number of stomachs. Items found were identified to the lowest identifiable taxonomic level (Merrit and Cummins, 1996; Bicudo and Menezes, 2006; Mugnai et al., 2010). Items that owing their high level of digestion could not be identified, were considered Nonidentified Organic Matter (NIOM) (Branco et al., 2002).

To compare differences in carapace length between sex, sites and months were used Kruskal-Wallis test complemented with the Student-Newman-Keuls $(\mathrm{p}<0,05)$ and to compare stomach contents between size, sex, molt stage, spatial distribution and seasonal changes were used the chi-square test $(\mathrm{p}<$ 0.05).

\section{Results ANd Discussion}

We collected 430 shrimps of the species $M$. brasiliense in the Curral de Arame Stream, of these $112(26.05 \%)$ were males and 318 $(73.95 \%)$ were females, with carapace length ranging from 3.25 to $17.45 \mathrm{~mm}$ and 2.3 to $19.85 \mathrm{~mm}$, respectively.

The size comparison between the sampling sites and sex demonstrated differences $\mathrm{H}=90.3056$ ( $\mathrm{p}<0.001)$ between sexes but not between the sampling sites, otherwise when comparing between sex and month of sampling a significant differences was observed $\mathrm{H}=144.6169(\mathrm{p}<0.001)$ between the sexes in the months of September and March and in the sampling sites for both males and females (Fig. 2).
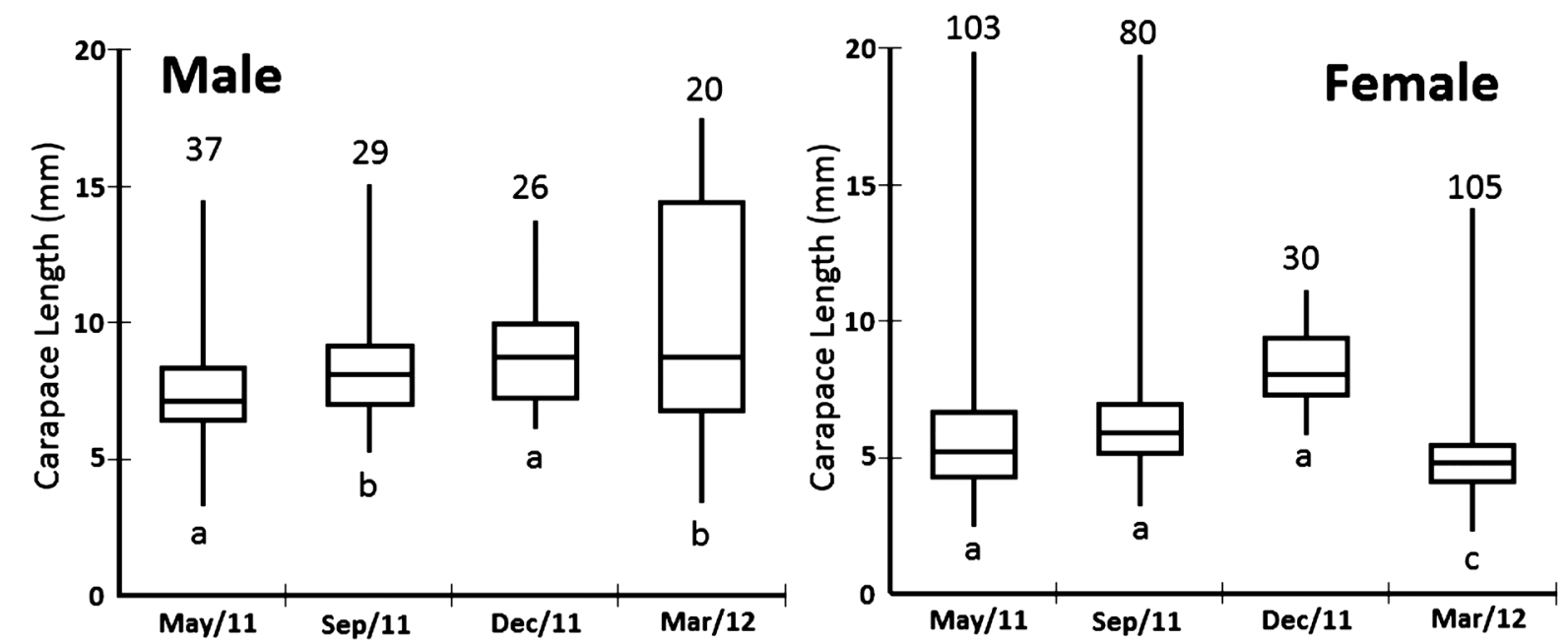

Figure 2. Box-plot (median, quartile and range) of the carapace length between male and female of M. brasiliense by sample month. The same letter below box-plot indicate that no has statistic difference between the box-plots, and the number above box representing total specimens caught in month. 
Table 1. Frequency distribution by size classes. $\mathrm{n}=$ number of individuals; $\%=$ percentage of the class in the total sample.

\begin{tabular}{lccccc}
\hline Size class $(\mathbf{m m})$ & Total $(\mathbf{n})$ & $\%$ & Females $(\mathbf{n})$ & Males $(\mathbf{n})$ & Empty Stomachs $(\mathbf{n})$ \\
\hline $2.30+5.23$ & 154 & 35.81 & 148 & 6 & 38 \\
$5.23+8.15$ & 175 & 40.70 & 120 & 55 & 48 \\
$8.15+11.08$ & 65 & 15.12 & 30 & 35 & 25 \\
$11.08+14.00$ & 22 & 5.12 & 14 & 8 & 4 \\
$14.00+16.93$ & 11 & 2.56 & 4 & 7 & 4 \\
$16.93+19.85$ & 3 & 0.70 & 2 & 1 & 1 \\
Total & 430 & & 318 & 112 & 120 \\
\hline
\end{tabular}

The size class that had the highest percentage was the class $5.23+8.15 \mathrm{~mm}$ length, representing $40.70 \%$ of the total, followed by the class $2.30+5.23 \mathrm{~mm}$ representing $35.81 \%$ indicating that the population consists mainly of juveniles individuals (Table 1).

Among males, 34 (30.36\%) have presented completely empty stomachs and 78 (69.64\%) presented stomach with content, even in small amount. For females, 86 (27.04\%) have presented completely empty stomachs and $232(72.96 \%)$ had content in the stomach.

Of the 430 individuals analyzed, 28\% had an empty stomach (stomach repletion 0 ), $22 \%$ with stomach repletion $1,8 \%$ with stomach repletion 2, 25\% with stomach repletion 3,and 17\% completely filled with stomach repletion 4 .

No significant difference $\left(\mathrm{p}>0.05 ; \mathrm{X}^{2}\right.$ $=9.2836$; $\mathrm{df} 4$ ) was found when analyzed the degree of stomach repletion by sex or spatial variation, as well as for the stomach repletion 2, 3 and 4 in the months of sampling, but a significant difference $(\mathrm{p}<0.05)$ was detected for the fullness of the stomach at degrees 0 and 1 (Fig. 3).

The more representative food items registered (Fig. 4) were not significantly different between males and females ( $>0.05$; $\mathrm{X}^{2}=5.6853$; df 9) evidencing a very similar pattern of food items, that can be because both sexes occupy the same habitat during most life cycle. Collins (1999) and Carnevali et al. (2012) observed similar results for other palaemonid shrimps, without significant

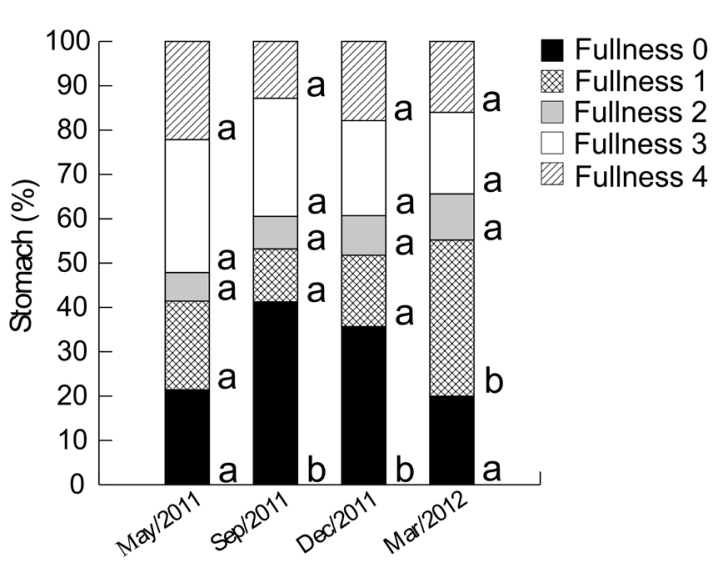

Figure 3. Fullness of the stomach of $M$. brasiliense by month of sampling. The letter beside column indicates the comparison within each degree of repletion between the months, the same horizontal letter indicate that no has statistic difference between the fullness of the stomach and the sazonal variation.

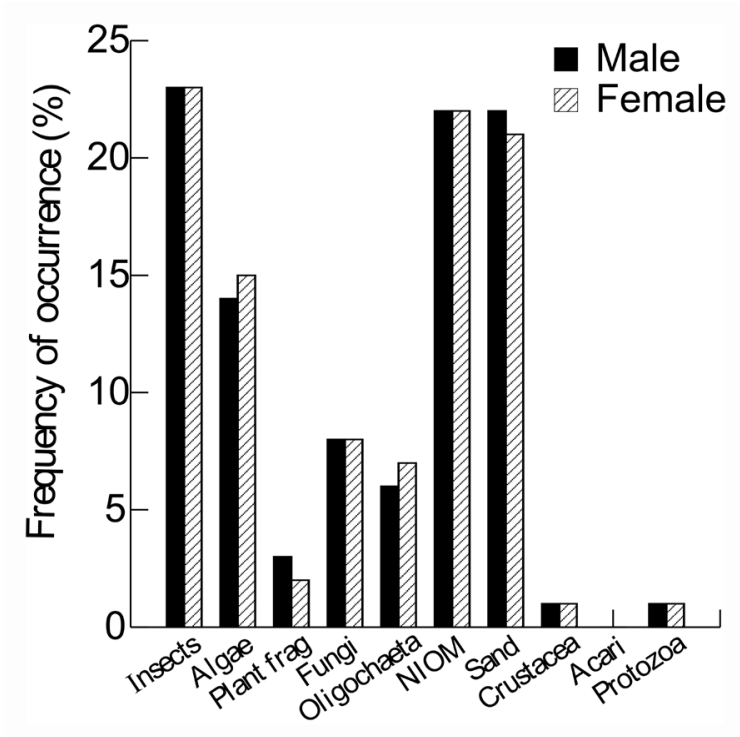

Figure 4. Percentage of main food items in the diet of males and females of $M$. brasiliense. 
difference in diet composition between sexes. Once there was no difference between the diet of males and females, analyses were performed with data of grouped sexes.

There was a significant difference for the items consumed between size classes, in the items Fungi ( $<$ 0.05, $\mathrm{X}^{2}=41.509$; df 5); Algae $\left(\mathrm{p}<0.05 ; \mathrm{X}^{2}=58.617\right.$; df 5); Plant fragment $\left(\mathrm{p}<0.05 ; \mathrm{X}^{2}=70.90 ; \mathrm{df} 5\right)$ and Oligochaeta $\left(\mathrm{p}<0.05 ; \mathrm{X}^{2}=38.699\right.$; df 5), of these, Algae, Plant and Fungi have increased their frequency of occurrence according to the increase of the carapace length, and the opposite being observed for the item Oligochaeta. Some authors such as Oh et al. (2001) and Spanjersberg et al. (2006) in studies developed on the feeding of different shrimp species have mentioned that the size and hardness of the preys could be directly related to the increase in size of individuals that capture (Fig. 5).

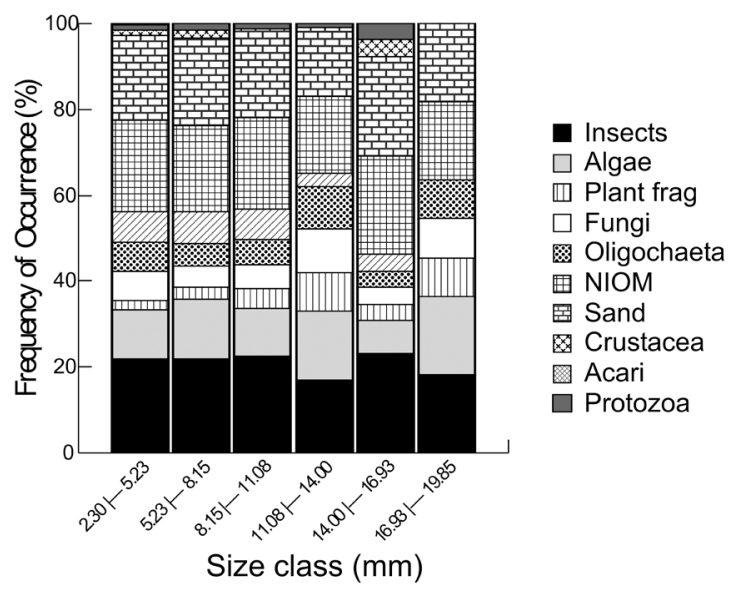

Figure 5. Frequency of occurrence (\%) of the items found in the stomach contents of $M$. brasiliense for size class ( $\mathrm{mm}$ ).

The qualitative analysis of the stomach content $M$. brasiliense has revealed a great array of items adding up a total of 34 (Table 2). The most important items by the frequency of occurrence (FO\%) were Insects with 94.52\%, followed by NIOM (Non-identified Organic Matter) with $90.00 \%$, and Sand with $87.10 \%$. This latter item is widely discussed in literature because it is not known if such intake is intentional or accidental. In this way, Branco and Verani (1997) have considered that the sand is accidentally ingested along with prey, but also stressed that it can be intentionally consumed if considered that the sediment is colonized by several microorganisms, such as Bacteria, Fungi and Protozoa, being the last two found in this study with FO $26.77 \%$ and 4.52\% respectively. According to Pru et al. (1994, apud Spanjersberg et al., 2006, p. 103) the sand besides being an item accidentally ingested, it also assists the process of crushing organic particles ingested, and can be used for the formation of a new exoskeleton (Choy, 1986). The item Oligochaeta had frequency of occurrence of $29.68 \%$ and Plant fragment had $14.52 \%$.

Among Insects that could be identified due to the presence of specific parts, the family Chironomidae (Diptera) occurred with the highest frequency, occurring in almost nearly half of the stomachs containing food, similarly to Collins (1999), Carnevali et al. (2012) for other species. The orders Ephemeroptera and Trichoptera have had a frequency of occurrence of $18.06 \%$ and $9.35 \%$ respectively, representing important items in the diet of $M$. brasiliense. The other orders, such as Coleoptera, Plecoptera, Odonata, Megaloptera and Hymenoptera, have presented a lower frequency of occurrence. Aquatic insects are items constantly found in stomach content analysis in crustacean and fish, and are important in the maintenance of the food chain because they occupy almost all levels (Johnson and Triplehorn, 2004).

Among Crustacea found in the stomach content, stands out the order Cladocera represented by the genus Daphnia sp. (FO\% $=3.22$ ). Cladocerans have been registered by several other authors (Collins, 1999; Albertoni et al., 2003; Jimoh et al., 2011; Carnevali et al., 2012). It was also verified locomotor appendages, part of the rostrum and antenna of $M$. brasiliense $(\mathrm{FO} \%=1.93)$. Probably the ingestion of these parts is a mechanism to obtain calcium carbonate to form a new exoskeleton, however Carvalho and Collins (2011) have stated that the cannibalism is common given the competition for food, space and sexual partner. Araujo and Valenti (2005) argued that species of the genus Macrobrachium are competitive, with possible cannibalism and social stress, which was proved by Souza 
Table 2. Frequency of Occurrence for the food items found in the stomach of M. brasiliense.

\begin{tabular}{|c|c|c|c|c|c|}
\hline Food Items & $\begin{array}{c}\text { FO \% } \\
\text { May/2011 } \\
\end{array}$ & $\begin{array}{c}\text { FO \% } \\
\text { Sept./2011 } \\
\end{array}$ & $\begin{array}{c}\text { FO \% } \\
\text { Dec./2011 } \\
\end{array}$ & $\begin{array}{c}\text { FO \% } \\
\text { Mar./2012 } \\
\end{array}$ & $\begin{array}{c}\text { FO \% } \\
\text { Total } \\
\end{array}$ \\
\hline Phylum Sarcomastigophora & 2.73 & 4.69 & 2.78 & 7.00 & 4.52 \\
\hline Phylum Heterokontophyta & 8.18 & 3.13 & 2.78 & 3.00 & 4.84 \\
\hline Class Bacillariophyceae (Diatom) & 62.73 & 54.69 & 25.00 & 39.00 & 49.03 \\
\hline Phylum Chrysophyta & 0.91 & 0.00 & 2.78 & 0.00 & 0.64 \\
\hline Phylum Rodhophyta & 0.91 & 0.00 & 0.00 & 0.00 & 0.32 \\
\hline Phylum Chlorophyta & 3.64 & 0.00 & 5.56 & 0.00 & 1.93 \\
\hline Genus Spirogyra & 4.55 & 1.56 & 5.56 & 3.00 & 3.55 \\
\hline Class Chlorophyceae & 4.55 & 0.00 & 0.00 & 0.00 & 1.6 \\
\hline Plant fragment & 15.45 & 3.13 & 8.33 & 23.00 & 14.52 \\
\hline Fungi & 57.27 & 9.38 & 5.56 & 12.00 & 26.77 \\
\hline \multicolumn{6}{|l|}{ Phylum Annelida } \\
\hline Class Oligochaeta - Tubificida & 17.27 & 48.44 & 25.00 & 33.33 & 29.68 \\
\hline Class Hirudina & 0.91 & 0.00 & 0.00 & 0.00 & 0.32 \\
\hline Insects (fragments) & 84.45 & 96.88 & 100.0 & 86.00 & 89.68 \\
\hline \multicolumn{6}{|l|}{ Phylum Arthropoda } \\
\hline \multicolumn{6}{|l|}{ Subphylum Cheliceriformes } \\
\hline Order Acari & 0.91 & 1.56 & 2.78 & 3.00 & 1.93 \\
\hline \multicolumn{6}{|l|}{ Subphylum Crustacea } \\
\hline \multicolumn{6}{|l|}{ Order Cladocera } \\
\hline Genus Daphnia & 0.91 & 6.25 & 2.78 & 4.00 & 3.22 \\
\hline \multicolumn{6}{|l|}{ Order Decapoda } \\
\hline M. brasiliense & 1.82 & 1.56 & 2.78 & 2.00 & 1.93 \\
\hline ClassCopepoda & 0.00 & 0.00 & 0.00 & 1.00 & 0.32 \\
\hline \multicolumn{6}{|l|}{ Subphylum Hexapoda } \\
\hline \multicolumn{6}{|l|}{ Class Insecta } \\
\hline Order Coleoptera & 2.73 & 0.00 & 0.00 & 5.00 & 2.58 \\
\hline Order Ephemeroptera & 15.45 & 17.19 & 25.00 & 19.00 & 18.06 \\
\hline Order Plecoptera & 1.82 & 0.00 & 8.33 & 0.00 & 1.61 \\
\hline Order Trichoptera & 12.73 & 7.81 & 11.11 & 6.00 & 9.35 \\
\hline Order Odonata & 3.64 & 0.00 & 1.82 & 0.00 & 1.93 \\
\hline Order Megaloptera & 0.00 & 0.00 & 2.78 & 0.00 & 0.32 \\
\hline Order Lepdoptera & 0.00 & 0.00 & 0.00 & 1.00 & 0.32 \\
\hline \multicolumn{6}{|l|}{ Order Hymenoptera } \\
\hline Family Formicidae & 0.00 & 3.13 & 0.00 & 0.00 & 0.64 \\
\hline Order Diptera & 11.82 & 3.13 & 5.56 & 7.00 & 7.74 \\
\hline Family Chironomidae & 35.45 & 53.13 & 33.33 & 32.00 & 37.74 \\
\hline Subfamily Tanypodinae & 0.91 & 1.56 & 0.00 & 0.00 & 0.64 \\
\hline Subfamily Orthocladiinae & 0.91 & 0.00 & 0.00 & 1.00 & 0.64 \\
\hline Subfamily Chironominae & 1.82 & 0.00 & 0.00 & 0.00 & 0.64 \\
\hline Genus Polipedium & 1.82 & 0.00 & 0.00 & 0.00 & 0.64 \\
\hline Genus Stenochironomus & 5.45 & 3.13 & 0.00 & 6.00 & 4.52 \\
\hline Insects (fragments) & 84.45 & 96.88 & 100.0 & 86.00 & 89.68 \\
\hline Sand & 87.27 & 95.31 & 97.22 & 78.00 & 87.1 \\
\hline
\end{tabular}


and Singer-Brugiolo (2001) who observed cannibalistic behavior among $M$. rosenbergii shrimps in laboratory.

Algae were also present in the stomach, representing $55.81 \%$ of the total sample. It was recorded numerous genera from different phyla. The most frequent were Diatoms (FO\% = 49.03), followed by Algae of the family Bacillariophyceae $(\mathrm{FO} \%=4.52)$, Spirogyra sp. $(\mathrm{FO} \%=3.55)$, also genera Spiniferomonas sp., Nitzchia sp., Hydrodictyon sp., Selenastrum sp., Chlorococcum sp., Peniun sp. and Closteriumsp., both with frequency of occurrence of $0.48 \%$. Collins (1999), Albertoni et al. (2003), Spanjersberg et al. (2006), Jimoh et al. (2011), and Carnevaliet al. (2012) also verified Algae in their studies, sometimes with the greatest importance, this item has a seasonal and size class variation significantly, but not having a significant spatial variation (Table 3 ).

Seasonal variations in the diet of $M$. brasiliense (Table 3) were observed, but not all food items found have presented significant difference $(\mathrm{p}>0.05)$, only the items Fungi $(\mathrm{p}<$ $\left.0.0001 ; \mathrm{X}^{2}=84.072 ; \mathrm{df} 3\right) ;$ Algae $\left(\mathrm{p}=0.002 ; \mathrm{X}^{2}\right.$ = 14.795; df 3); Oligochaeta $\left(\mathrm{p}=0.0006 ; \mathrm{X}^{2}=\right.$ 17.222; df 3) and Plant fragment $(\mathrm{p}=0.0004$, $\mathrm{X}^{2}=17.963$; $\mathrm{df} 3$ ), analyzed by the chi-square test have shown significant difference in the frequency of occurrence during the study, and the items Algae and Fungi have had a higher frequency of occurrence in May 2011, with a reduction in September and December 2011, and a lower value in March 2012.
The items Plant fragment and Oligochaeta presented an inverse pattern, the first was more frequent in May 2011 and March 2012, and Oligochaeta was more frequent in September 2011 and March 2012. Only the items Fungi $\left(p=0.0396 ; X^{2}=6.459 ; d f 2\right)$ and Oligochaeta $\left(\mathrm{p}=0.0028 ; \mathrm{X}^{2}=11.734 ; \mathrm{df}\right.$ 2) have obtained a significant difference in the spatial variation, with the first being the most frequent at the site 2 , and less frequent at the site 3 , and the second being more frequent at the site 3 and less frequent at the site 2 .

Moreover, the feeding of these shrimps has varied according to their molt stage (Table 3), the food intake was not significantly different between stages, except for the items Fungi ( $<$ 0.0001; $\mathrm{X}^{2}=32.71$; df 2) and Plant fragment $\left(p=0.0178 ; X^{2}=8.056 ; d f 2\right)$. For the molt stage $\mathrm{A}$, the items with higher $\mathrm{FO}$ were Insects remains (86.67), NIOM (80) and sand (73.33), without record of Fungi, Crustacea, Acari, and Protozoa; the molt stage B had Insects remains/sand (90.79), NIOM (89.47), Algae (51.32) and Oligochaeta (26.67) as the most frequent items, and Crustacean, Acari, Protozoa, Plant fragments and Fungi as the least frequent; and in the molt stage $\mathrm{C}$, the most frequent items were Insects remains (95.89), NIOM (90.87), sand (86.76), Algae (58.45) and Fungi (32.42), and with lower frequencies the same items cited for the stage B.

Studies on Macrobrachium species have indicated that, as observed in the present study, this genus has a diet made up by several food items. Albertoni et al. (2003) and Jimoh

Table 3. Chi-square test $\left(\mathrm{X}^{2}\right)$ applied to the components of the diet of $M$. brasiliense for grouped sex, seasonality, spatial variation, class size and molting stage variation. $\left({ }^{*}\right): \mathrm{P}<0.05$. (-) (Data insufficient to calculate chi-square test).

\begin{tabular}{lccccc}
\hline Food Items & $\begin{array}{c}\text { Sex } \\
\text { Variation }\left(\mathbf{X}^{\mathbf{2}}\right)\end{array}$ & $\begin{array}{c}\text { Seasonal } \\
\text { Variation }\left(\mathbf{X}^{\mathbf{2}}\right)\end{array}$ & $\begin{array}{c}\text { Spatial } \\
\text { Variation }\left(\mathbf{X}^{\mathbf{2}}\right)\end{array}$ & $\begin{array}{c}\text { Size Class } \\
\text { Variation }\left(\mathbf{X}^{\mathbf{2}}\right)\end{array}$ & $\begin{array}{c}\text { Molt Stage } \\
\text { Variation }\left(\mathbf{X}^{\mathbf{2}}\right)\end{array}$ \\
\hline Insecta & 0.036 & 1.253 & 0.077 & 1.292 & 0.468 \\
Algae & 0.056 & $14.795^{*}$ & 2.576 & $58.617^{*}$ & 3.468 \\
Plantfragment & 1.234 & $17.963^{*}$ & 0.307 & $70.9^{*}$ & $8.056^{*}$ \\
Fungi & 1.325 & $84.072^{*}$ & $6.459^{*}$ & $41.509^{*}$ & $32.71^{*}$ \\
Oligochaeta & 0.513 & $17.222^{*}$ & $11.734^{*}$ & $38.699^{*}$ & 1.542 \\
NIOM & 0.001 & 1.153 & 0.077 & 1.997 & 0.806 \\
Sand & 0.602 & 2.578 & 0.299 & 1.787 & 1.999 \\
Crustacea & -- & 2.59 & -- & -- & -- \\
Acari & -- & -- & -- & -- & -- \\
Protozoa & 0.622 & -- & $22.396^{*}$ & - \\
\hline
\end{tabular}


et al. (2011) found similar results related to the wide composition of the diet of $M$. acanthurus, M. lamarrei and $M$. vollenhovenii, respectively. Studies on other genera also evidenced that shrimps are usually omnivorous and feed on a wide variety of food (Chong and Sasekumar, 1981; Collins, 1999; Branco and Junior, 2001; Spanjersberg et al., 2006; Carnevali et al., 2012).

In summary, the results of the qualitative analysis of the stomach content of $M$. brasiliense, using the frequency of occurrence, have shown that the species has omnivorous habit, being registered diverse items, such as Insects remains particularly Chironomidade larvae, Diatoms, Oligochaeta, Plant fragment, filamentous Fungi, Sand, or Non-identified Organic Matter. Furthermore, it was observed a spatial and seasonal variation in the feeding of this species, as well as different size classes feed on different prey.

ACKNOWLEDGMENTS - The authors express their gratitude to the laboratory staff, especially to Ellen B. Siqueira, Jaqueline N. Pereira, Lana Carla F. Vieira and Nathaskia S. Pereira for the partnership in performing the samplings and help in measuring the size and weight of shrimps.

\section{REFERENCES}

Aguirre-León, A. and Yáńez-Arancibia, A. 1984. Las mojarras de la Laguna de Términos: Taxonomía, Biología Ecología y Dinámica Trófica (Pisces: Gerreidae). Anales del Instituto de Ciencias del Mar y Limnología, 2: 1-92.

Albertoni, E.F.; Palma-Silva, C. and Esteves, F.A. 2003. Overlap of dietary niche and electivity of three shrimp species (Crustacea, Decapoda) in a tropical coastal lagoon (Rio de Janeiro, Brazil). Revista Brasileira de Zoologia, 20(1): 135-140.

Araujo, M.C. and Valenti,W.C. 2005. Manejo alimentar de pós-larvas do camarão-da-amazônia, Macrobrachium amazonicum, em berçário I. Acta Scientiarum - Animal Sciences, 27(1): 67-72.

Barros, H.P. and Valenti, W.C. 1997. Comportamento alimentar do camarão de água doce, Macrobrachium rosenbergii (De Man) (Crustacea, Palaemonidae) durante a fase larval: análise qualitativa. Revista Brasileira de Zoologia, 14(4): 785 - 793.

Bicudo, C.E.M. and Menezes, M. 2006. Gêneros de Algas de Águas Continentais do Brasil: chave para identificação e descrição. $2^{\text {ed }}$.São Carlos: Rima, 502p.

Branco, J.O. and Verani, J.R. 1997. Dinâmica da alimentação natural de Callinectes danae Smith (Decapoda, Portunidae) na Lagoa da Conceição, Florianópolis, Santa Catarina, Brasil. Revista Brasileira de Zoologia, 14(4): 1003-1018.
Branco, J.O. and Junior, H.C.M. 2001. Alimentação natural do camarâo sete-barbas, Xiphopenaeus kroyeri (Heller) (Crustacea, Decapoda), na Armação do Itapocoroy, Penha, Santa Catarina. Revista Brasileira de Zoologia, 18(1): 53-61.

Branco, J.O.; Lunardon-Branco, M.J.; Verani, J.R.; Schveitzer, R.; Souto, F.X. and Vale, W.G. 2002. Natural diet of Callinectes ornatus Ordway, 1863 (Decapoda, Portunidae) in the Itapocory Inlet, Penha, SC, Brazil. Archives of Biology and Technology, 45(1): 35-40.

Carnevali, R.P.; Collins, P.A. and Neiff, A.S.G.P. 2012. Trophic ecology of the freshwater prawn, Pseudopalaemon bouvieri (Decapoda: Palaemonidae) in Northeastern Argentina, with remarks on population structure. Revista de Biologia Tropical, 60(1): 305-316.

Carvalho, D.A. and Collins, P.A. 2011. Ontogenetic predation capacity of Macrobrachium borellii (Caridea: Palaemonidae) on prey from littoral-benthic communities. Nauplius, 19(1): 71-77.

Chong, V.C. and Sasekumar, A. 1981.Food and feeding habits of the white prawn Penaeus merguiensis. Marine Ecology Progress Series, 5(20): 185-191.

Choy, S.C.1986. Natural diet and feeding habits of the crabs Liocarcinus puber and L. holsatus (Decapoda, Brachyura, Portunidae).Marine Ecology Progress Series, 31(6): 87-99.

Coelho, P.A. and Ramos-Porto, M. 1985. Camaróes de água doce do Brasil: distribuição geográfica. Revista Brasileira de Zoologia,2(4): 405-410.

Collins, P.A. 1999. Feeding of Palaemonetes argentinus (Decapoda: Palaemonidae) from an oxbow lake of the Paraná River, Argentina. Journal of Crustacean Biology, 19(3): 485-492.

De Grave, S. and C.H.J.M. Fransen. 2011. Carideorum catalogus: the recent species of the dendrobranchiate, stenopodidean, procarididean and caridean shrimps (Crustacea: Decapoda). Zoologische Mededelingen, 85(9): 195-589.

García-Dávila, C.R.; Alcantara, F.; Vasquez, E. and Chujandama, M. 2000. Biologia reprodutiva do camarão Macrobrachium brasiliense (Heller, 1862) (Crustacea: Decapoda: Palaemonidae) em igarapés de terra firme da Amazônia Peruana. Acta Amazonica, 30(4): 653-664.

Hyslop, E.J.1980. Stomach contents analysis - a review of methods and their applications. Journal of Fish Biology, 17: 411-429.

Jimoh, A.A.; Clarke, E.O.; Whenu, O.O. and Adeoye, H.B. 2011. Food and feeding habits of the African river prawn (Macrobrachium vollenhovenii, Herklots, 1857) in Epe Lagoon, southwest Nigeria. International Journal of Fisheries and Aquaculture, 3(1): 10-15.

Johnson N.F. and Triplehorn, C.A. 2004. Borror and De Long's Introduction to the Study of Insects. $7^{\text {the }}$ edition. Belmont, USA. Thomson Brooks.

Josileen, J. 2011. Food and feeding of the blue swimmer crab, Portunus pelagicus (Linnaeus, 1758) (Decapoda, Brachyura) along the Coast of Madapam, Tamil Nadu, India. Crustaceana, 84(10): 1169-1180.

Mantelatto, F.L. and Barbosa, L.R. 2005. Population structure and relative growth of freshwater prawn Macrobrachium brasiliense (Decapoda, Palaemonidae) from São Paulo State, Brazil. Acta Limnologica Brasiliensia, 17(3): 245255. 
McLaughlin, P.A. and Hebard.F. 1961. Stomach contents of the Bering Sea King crab. Bulletin International North Pacific Fisheries Commission, 5: 5-8.

Melo, G.A.S. 2003. Manual de identificação de Crustacea Decapoda de água doce do Brasil. São Paulo: Ed. Loyola. 420p.

Merrit, R.W. and Cummins, K.W. 1996. An introduction to the aquatic Insects of North America. Duduque: Kendal/ Hunt, 862p.

Mugnai, R.; Nessimian, J.L. and Baptista, D.F. 2010. Manual de identificação de invertebrados aquáticos do Estado do Rio de Janeiro. Rio de Janeiro: Technical Books, 176p.

Oh, C.W.; Hartnoll, R.G. and Nash, R.D.M. 2001. Feeding ecology of the common shrimp Crangon crangon in Port Erin Bay, Isle of Man, Irish Sea. Marine Ecology Progress Series, 214: 211-223.

Pantaleão, J.A.F.; Gregati, R.A.; Taddei, F.G. and Costa, R.C. 2011. Morphology of the first larval stage of Macrobrachium brasiliense (Heller, 1868) (Caridea: Palaemonidae). Nauplius, 19(1): 79-85.

Passano, L.M. 1960. Molting and its control. P. 473-536. In: Waterman. T.H. (Ed.) The Physiology of Crustacea: Metabolism and Growth (Vol. 1). Academic Press. New York, USA.

Pereira, M.G.C. and Chacur, M.M. 2009. Estrutura populacional de Macrobrachium brasiliense (Crustacea, Palaemonidae) do Córrego Escondido, Batayporá, Mato Grosso do Sul, Brasil. Revista Biologia Neotropical, 6(1):75-82.

Pileggi, L.G.; Magalhães, C.; Bond-Buckup, G. and F.L. Mantelatto. 2013. New records and extension of the known distribution of some freshwater shrimps in Brazil. Revista Mexicana de Biodiversidad, 84(2): 563-574.

Pru, E.P.; Millán, J.; Robaina G. and Cervigón, F. 1994. Análisis del contenido gastrointestinal del camarón Penaeus brasiliensis Latreille, 1817 (Decapoda: Penaeidae) cultivado en estanques con fondo de tierra. Revista Latinoamericana de Acuicultura 43: 17-24.

Roux, A.; Piñero, R.; Moriondo, P. and Fernández, M. 2009. Diet of the red shrimp Pleoticus muelleri (Bate, 1888) in Patagonian fishing grounds, Argentine. Revista de Biología Marina y Oceanografía, 44(3): 775-781.

Souza, M.C. and Singer-Brugiolo, S.S. 2001. Efeito da amputação das quelas sobre o comportamento canibalístico de Macrobrachium rosenbergii (De Man, 1879) (Crustacea, Palaemonidae) em condiçóes de laboratório. Revista Brasileira de Zoociências, 3(1): 7-19.

Spanjersberg, G.; Roux, A. and Caille, G. 2006. Composición cualitativa de la dieta del camarón Artemesia longinaris Bate, 1888 (Decapoda, Penaeidae) de Bahía Engaño (Chubut), Argentina. Boletín del Instituto Español de Oceanografía, 22(1-4): 99-111.

Vásquez, E.; Chujandama, M.; Gárcia, C. and Alcántara, F. 2000.Caracterización del hábitat del camarón Macrobrachium brasiliense en ambientes acuáticos de la Carretera Iquitos-Nauta. Folia Amazônica, 10(1-2): 5771.

Zavala-Camin, L.A.1996. Introdução ao estudo sobre alimentação natural de peixes. Maringá: EDUEM, 129p. 